\title{
Ectopic ACTH-secreting pituitary adenoma of the sphenoid sinus: case report of endoscopic endonasal resection and systematic review of the literature
}

\author{
Justin Seltzer, BA, ${ }^{1}$ Joshua Lucas, MD, ${ }^{1}$ Deborah Commins, MD, PhD, ${ }^{2}$ Olga Lerner, MD, ${ }^{3}$ \\ Alexander Lerner, MD, ${ }^{4}$ John D. Carmichael, MD, ${ }^{5}$ and Gabriel Zada, MD ${ }^{1}$
}

Departments of ${ }^{1}$ Neurosurgery, ${ }^{2}$ Pathology, and ${ }^{4}$ Radiology and ${ }^{5}$ Division of Endocrinology, Department of Medicine, Keck School of Medicine of USC, Los Angeles, California; and ${ }^{3}$ Providence Saint Joseph Medical Center, Burbank, California

Ectopic pituitary adenomas are exceedingly rare entities that are often misdiagnosed. The resulting delay in diagnosis may be particularly concerning in the case of Cushing syndrome caused by an ectopic adrenocorticotropic hormone (ACTH)-secreting pituitary adenoma. Although the total resection of ectopic adenomas results in rapid and durable remission, persistent Cushing syndrome is often associated with permanently damaging invasive procedures and significantly higher risk of mortality.

The authors report the case of a 48-year-old man with ACTH-dependent Cushing syndrome. On the morning before surgery, his serum cortisol measured $51 \mu \mathrm{g} / \mathrm{dl}$, his ACTH level was $195.7 \mathrm{pg} / \mathrm{ml}$, and his urinary free cortisol level was $2109 \mu \mathrm{g} /$ day. Serum cortisol was not suppressed with the administration of high-dose dexamethasone. Imaging showed separate masses in both the sphenoid sinus and the pituitary gland, complicating the diagnostic process and requiring pathological assessment of both masses. No other abnormalities were found on thoracic, abdominal, or pelvic scans. Gross-total resection of both lesions was accomplished via an endoscopic endonasal transsphenoidal approach. Pathology confirmed an ectopic ACTH pituitary adenoma of the sphenoid sinus and a Crooke hyaline change of the pituitary gland. The patient achieved stable hormonal remission without significant postoperative complications, returned to full activity within 3 months, and remained disease free nearly 1 year after tumor resection.

In a systematic literature review, the authors identified 41 cases of ectopic ACTH-secreting pituitary adenomas, including 18 arising in the sphenoid sinus without direct involvement of the sella. Including the case described here, the total number of ectopic ACTH pituitary adenomas arising in the sphenoid sinus was 19, and the total number of ectopic ACTH pituitary adenomas without regard to location was 42 . For the 19 patients with adenomas found in the sphenoid sinus, ages ranged from 16 to 76 years, and there were 15 women and 4 men. The mean and median diameters of the resected sphenoid masses were 13.9 and $8 \mathrm{~mm}$, respectively, with a range of 3-55 $\mathrm{mm}$. Seven were microadenomas $(<1 \mathrm{~cm})$. Fifteen of the 19 cases reported serum ACTH and morning cortisol levels, the means of which were $106.7 \mathrm{pg} /$ $\mathrm{ml}$ and $32.5 \mu \mathrm{g} / \mathrm{dl}$, respectively. Gross-total tumor resection was achieved in all patients except one, and in all of them durable hormonal remission of Cushing syndrome was achieved (mean follow-up time 20 months).

Ectopic pituitary adenomas are rare but important causes of Cushing syndrome and related endocrinopathies, particularly because of the rapid onset and severity of symptoms with atypical presentation. Ectopic pituitary adenomas, especially those in the nasal cavity, nasopharynx, or paranasal sinuses, are easily misidentified. Any patient presenting with signs and symptoms of Cushing syndrome without any obvious pituitary adenoma or other sources of hypercortisolemia should be thoroughly screened for an ectopic adenoma. However, as with the case presented here, the coincident existence of a sellar mass should not preclude the possibility of an ectopic source. There should be a high degree of clinical suspicion for any mass in the general area surrounding the sella when evaluating Cushing syndrome.

http://thejns.org/doi/abs/10.3171/2014.10.FOCUS14685

KEY WORDS ectopic; ACTH; pituitary adenoma; sphenoid sinus; endoscopic; endonasal; transsphenoidal

ABBREVIATION ACTH = adrenocorticotropic hormone.

SUBMITTED October 1, 2014. ACCEPTED October 30, 2014

INCLUDE WHEN CITING DOI: 10.3171/2014.10.FOCUS14685.

DISCLOSURE Dr. Carmichael has served as a consultant for Corcept Therapeutics, Inc., and Novartis and has received non-study-related clinical or research support from Novartis; the other authors report no conflict of interest concerning the materials or methods used in this study or the findings specified in this paper. 
$\mathrm{C}$ USHING syndrome was first described and characterized in a series of 10 patients by Dr. Harvey Cushing in $1932 .{ }^{4}$ Since that time, our understanding of the disease, especially its varied etiologies and diagnostic criteria, has been continuously refined. We now understand that Cushing syndrome is caused by the overproduction of cortisol, and its symptoms are manifestations of prolonged hypercortisolemia. ${ }^{27}$ Common signs and symptoms include central obesity, rapid weight gain, proximal muscle weakness, hypertension, irritability, diabetes mellitus, easy bruising, abdominal striae, moon facies, dorsocervical fat deposition, and acne. ${ }^{28}$ Cushing disease is caused by an adrenocorticotropic hormone (ACTH)-producing pituitary adenoma that stimulates excess cortisol production by the adrenal glands and is the most common cause of Cushing syndrome. ${ }^{2,13}$

Although most cases of Cushing syndrome are caused by an ACTH pituitary adenoma, a pituitary adenoma can be "ectopic" (i.e., it can occur outside of the sella turcica without any direct connection to the pituitary gland). ${ }^{40}$ Ectopic pituitary adenomas are rare lesions; fewer than 100 cases were reported over the past century. We report here the case of a patient with Cushing syndrome and an ectopic ACTH-secreting pituitary adenoma confined to the sphenoid sinus. In addition, a systematic literature review was performed to identify previous cases of ectopic ACTH-secreting pituitary adenomas; the clinical presentations, treatments, findings, and postoperative courses of these patients presenting with ectopic ACTH adenomas are discussed in this review.

\section{Methods}

\section{Overview of Systematic Literature Review}

A systematic literature review was performed to find all published cases of ectopic ACTH pituitary adenomas regardless of anatomical location. A subanalysis of these articles focused on cases of ectopic ACTH adenomas arising within the sphenoid sinus.

\section{Search Strategy and Terms}

A search for all ectopic ACTH pituitary adenomas was performed according to Preferred Reporting Items for Systematic Reviews and Meta-Analyses (PRISMA) criteria and using the PubMed database with the string "ectopic pituitary" to capture the large number of title variations present. This same strategy was applied to the search for ectopic ACTH adenomas of the sphenoid sinus. For this search, the string (("ectopic pituitary") AND ("sphenoid")) was used in PubMed. The 2 searches were performed separately to decrease the possibility of missed cases.

\section{Inclusion/Exclusion Criteria}

For the general search for articles pertaining to ectopic ACTH pituitary adenomas, the inclusion criteria were functional ACTH secretion, ectopic location without communication with the pituitary gland, pathologically verified pituitary adenoma, and case report or case series presentation. The rejection criteria included incorrect tumor type, non-English-language articles, nonspecific or combined case data, and no or incomplete outcome re- sults. Full articles were predominantly used to determine inclusion and exclusion; however, abstracts were used for screening when the full article was not available. The search for and subanalysis of ectopic ACTH adenoma of the sphenoid sinus involved the same exclusion criteria as the general search. The inclusion criteria also remained nearly the same; the only modification was the specific location within the sphenoid sinus.

\section{Case Report}

\section{History}

A 48-year-old man presented with symptoms and signs of Cushing syndrome, including hypertension, diabetes mellitus, memory dysfunction, proximal muscle weakness, easy bruisability, anxiety, and insomnia for 2 months before evaluation in our clinic. He developed rapidly progressive diabetes mellitus and electrolyte abnormalities over the 30-day period before diagnosis.

Laboratory results showed a morning serum cortisol level of $51 \mu \mathrm{g} / \mathrm{dl}$ (reference range 4-22 $\mu \mathrm{g} / \mathrm{dl}$ ) and an ACTH level of $195.7 \mathrm{pg} / \mathrm{ml}$ (reference range 6-50 pg/ml). His urinary free cortisol level was $2109 \mu \mathrm{g}$ /day (reference range 4-50 $\mu \mathrm{g} / \mathrm{day})$. The test results also revealed hypocalcemia, hyperglycemia, and hypogonadotropic hypogonadism. The patient was diagnosed with Cushing syndrome, treated with $200 \mathrm{mg}$ of oral ketoconazole 3 times daily, and referred for a neurosurgical consultation.

\section{Examination}

Evaluation of the patient in our clinic showed that he was obese (body mass index $41.5 \mathrm{~kg} / \mathrm{m}^{2}$ ) and hypertensive (blood pressure 165/105 $\mathrm{mm} \mathrm{Hg}$ ) despite receiving daily atenolol, lisinopril, and spironolactone therapy. The patient did not have many classical cushingoid features, likely because of the rapid onset of symptoms. Bilateral proximal lower-extremity weakness (Grade 4/5) with tremor, gait disturbances, and 1+ pitting edema were noted. The patient reported frequent nocturia and heat intolerance.

Further endocrine testing revealed a serum cortisol level of $48 \mu \mathrm{g} / \mathrm{dl}$ after the administration of $8 \mathrm{mg}$ of dexamethasone. MRI with and without Gd (Fig. 1) showed a $5-\mathrm{mm}$ nonenhancing mass in the left inferior pituitary gland and a $1.8-\mathrm{cm}$ enhancing mass on T1-weighted imaging, low signal intensity on T2-weighted imaging in the right superior sphenoid sinus, and complete separation from the sella turcica and pituitary gland. CT scans of the thorax, abdomen, and pelvis were negative for any masses.

A diagnosis of ACTH-dependent Cushing syndrome with a central source was made on the basis of the MRI findings and the negative $\mathrm{CT}$ results. Inferior petrosal sinus sampling was deferred because of unclear additional clinical benefit in the presence of the 2 masses in the sphenoid sinus and sella. Our decision to pursue surgery directly was informed by the high likelihood of at least 1 of the 2 identified masses being the root cause and by the fact that both masses could be resected during the same procedure. In addition, the low signal intensity of the sphenoid sinus mass on T2-weighted imaging helped distinguish it from sphenoid sinus disease and further informed our clinical decision making. 

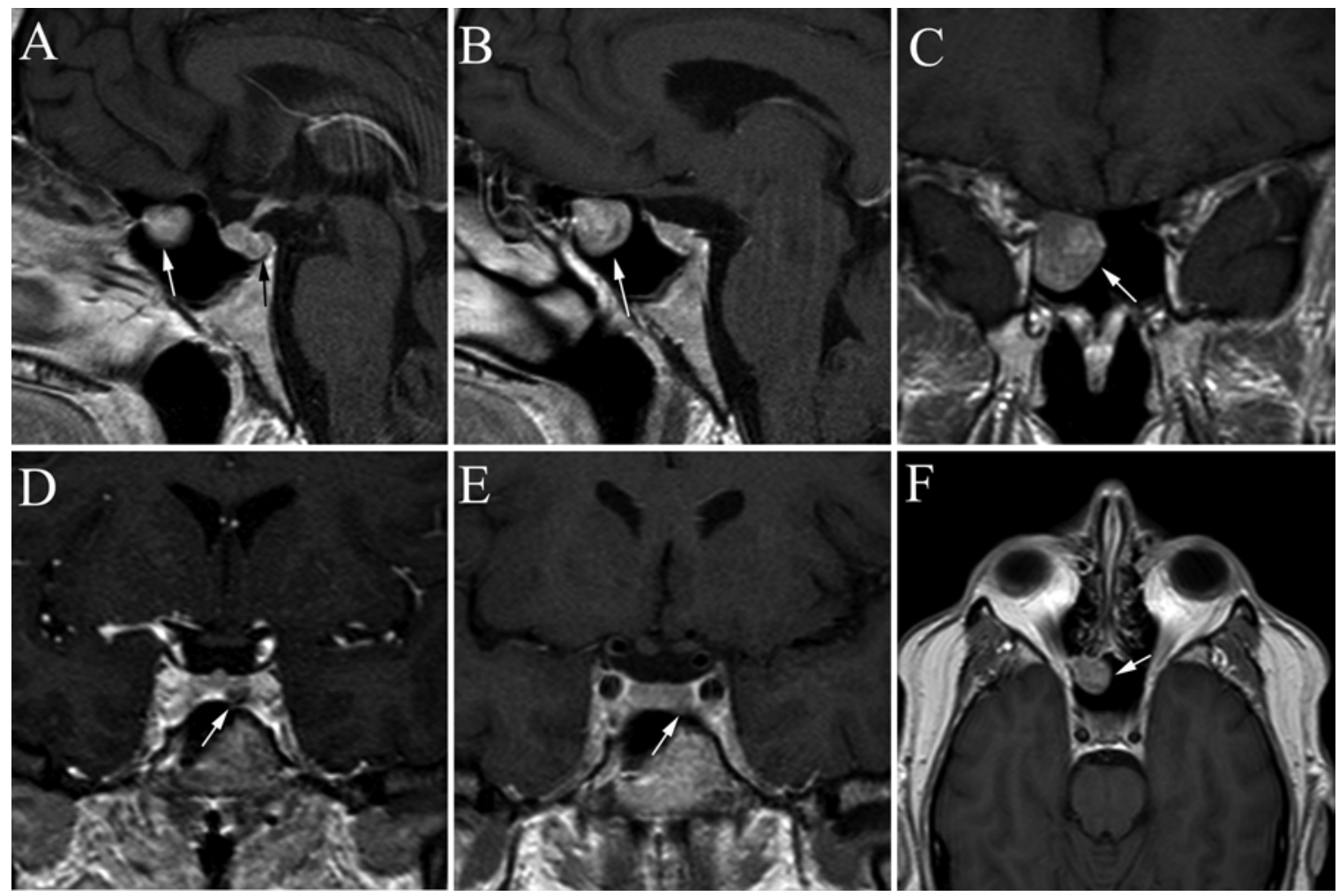

FIG. 1. Preoperative MR images showing the sphenoid sinus mass (white arrows in $\mathbf{A}-\mathbf{C}$ and $\mathbf{F}$ ). The sphenoid mass is distinct from the sella and pituitary gland ( $\mathbf{A}$ and $\mathbf{F}$ ). The sellar mass is visible in panels $\mathbf{A}$ (black arrow), D (white arrow), and $\mathbf{E}$ (white arrow).

\section{Operation}

An endoscopic endonasal transsphenoidal approach was taken to provide the greatest access to both the sphenoid sinus and the left sellar mass with the lowest risk to the patient. The patient's nasal cavity and right lower quadrant were prepared. Neuronavigation was then calibrated for use throughout the procedure. A $0^{\circ}$ endoscope was used to identify and lateralize the middle turbinates. The sphenoid ostia were then identified, cauterized, and widened. The nasal septum was then injected with lidocaine/epinephrine and incised vertically at the junction of the bony and cartilaginous septum. Bilateral nasal-mucosal flaps were developed, and the vomer was then removed using rongeurs. The anterior sphenoidotomy was widened by removing the sphenoid rostrum in a circumferential fashion.

After entry into the sphenoid sinus, a large mass was identified superiorly in the right sphenoid sinus (Fig. 2). The tumor was grossly removed using suction, tumor forceps, and ring curettes. This process resulted in a small CSF leak located in the posterior ethmoid roof along the skull base that was subsequently repaired using autologous fascia and fat from the patient's abdomen.

After gross-total resection of the sphenoid sinus mass, the bony floor of the sella was identified and removed using a Kerrison rongeur. Neuronavigation and micro-Dop-
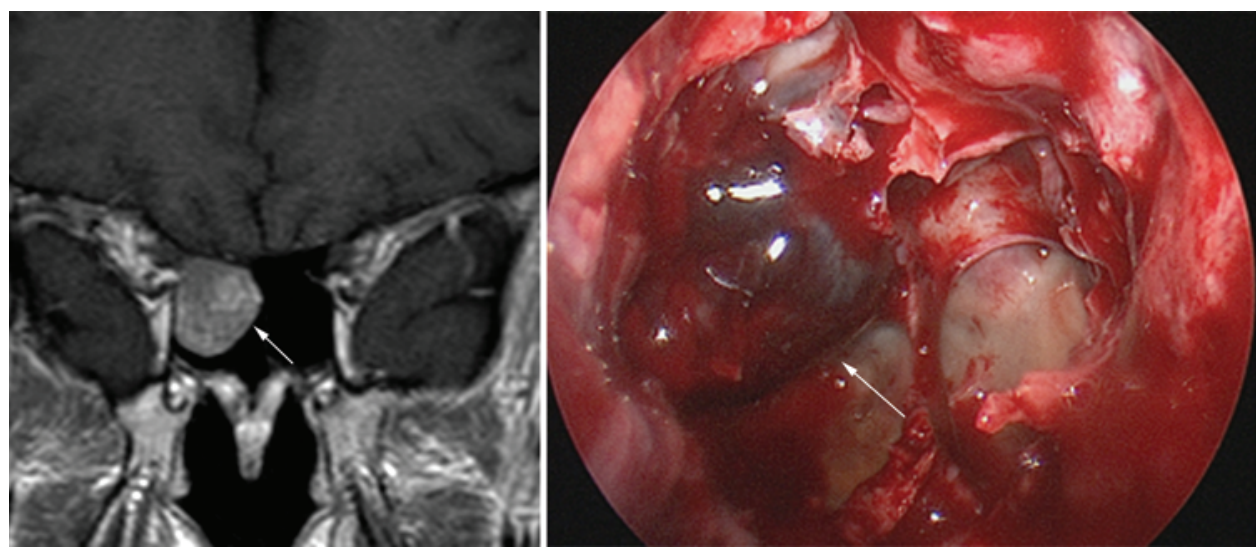

FIG. 2. Intraoperative photograph (right) showing the sphenoid sinus mass (white arrow) and a preoperative MR image for reference (left). 
pler were then used to confirm the location of the bilateral internal carotid arteries. Once safe margins were established, the dura was incised and the sellar contents were exposed. The second mass, located in the left aspect of the pituitary gland, was then identified and removed entirely by using ring curettes. The pituitary gland was preserved, and no intrasellar CSF leak was noted.

After resection of both lesions, a CSF leak repair of the ethmoidal skull base defect was performed by using a small amount of subcutaneous fat and abdominal fascia harvested from the right lower quadrant of the patient's abdomen. The fascia and fat were placed within the fovea ethmoidalis and covered with a layer of DuraGen collagen matrix. Successive layers of Surgicel absorbable cellulose hemostat and DuraSeal hydrogel were placed over the layer of DuraGen. The middle turbinate was then medialized to provide additional structural support. A small piece of fat was placed within the resection cavity of the sella turcica to obliterate the dead space in this region.

Once the repair was completed, the nasal cavity and nasopharynx were suctioned, Merocel nasal packs were inserted, and a lumbar drain was inserted at L4-5. The patient was then extubated and brought to the neurological intensive care unit in stable condition.

\section{Pathological Findings}

The sphenoid sinus tumor and the pituitary tumor were submitted separately to pathology and processed routinely to create H \& E-stained sections (Figs. 3 and 4). Both specimens were also stained for pituitary hormones, alpha subunit, and CAM5.2 (a low-molecular-weight cytokeratin) by standard immunohistochemical techniques. The sphenoid sinus tumor was also immunohistochemically stained for synaptophysin, chromogranin A, and proliferation-associated antigen Ki-67 (MIB-1).

The sphenoid sinus tumor stained positively for synaptophysin, CAM5.2, and ACTH (Fig. 5). Results of the

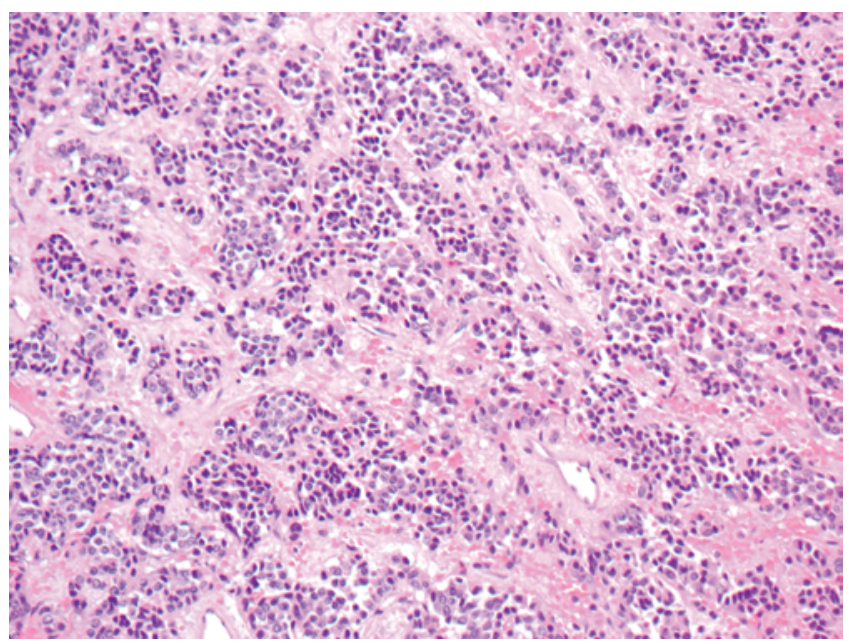

FIG. 3. H \& E-stained section of the sphenoid sinus tumor show moderately pleomorphic cells in irregular clusters. The cells had a neuroendocrine appearance with granular cytoplasm and nuclei with small basophilic nuclei. No mitotic figures were observed. No nonneoplastic anterior pituitary-type tissue was found in this specimen. Original magnification $\times 200$.

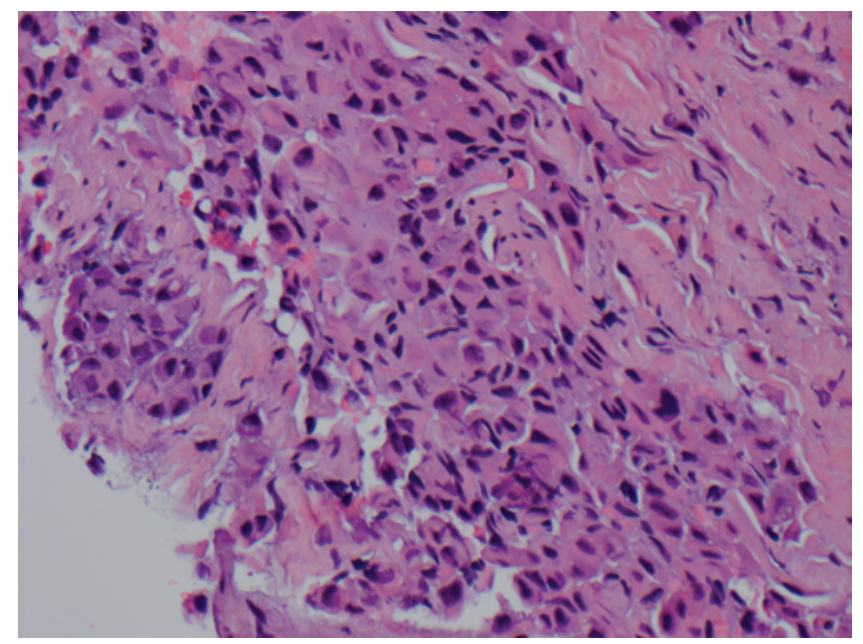

FIG. 4. H \& E-stained section of the pituitary tumor. A cluster of cells in the upper part of the tissue fragment shows a Crooke hyaline change. Original magnification $\times 400$.

stains for the other pituitary hormones, alpha subunit, and chromogranin A were negative. The percentage of nuclei positive for MIB-1 was less than $3 \%$.

The pituitary tumor specimen consisted of 3 small tissue fragments. Two of them were fibrotic anterior pituitary tissue, which was confirmed by immunohistochemistry to be positive for all the pituitary hormones and alpha subunit. These fragments contained scattered cells showing Crooke hyaline changes with no evidence of pituitary adenoma. The third fragment appeared to consist of fibrous tissue and numerous cells showing Crooke hyaline changes but tested negative for all pituitary hormones except for $\mathrm{ACTH}$, which appeared in a few cells. It has been reported, and is our experience, that better-developed Crooke hyaline changes stain less for ACTH.

\section{Postoperative Course}

The patient had a relatively benign postoperative course. Daily morning cortisol levels on the first 4 days after the operation were 13.2, 9.5, 10.5, and $18.1 \mu \mathrm{g} / \mathrm{dl}$ (ref-

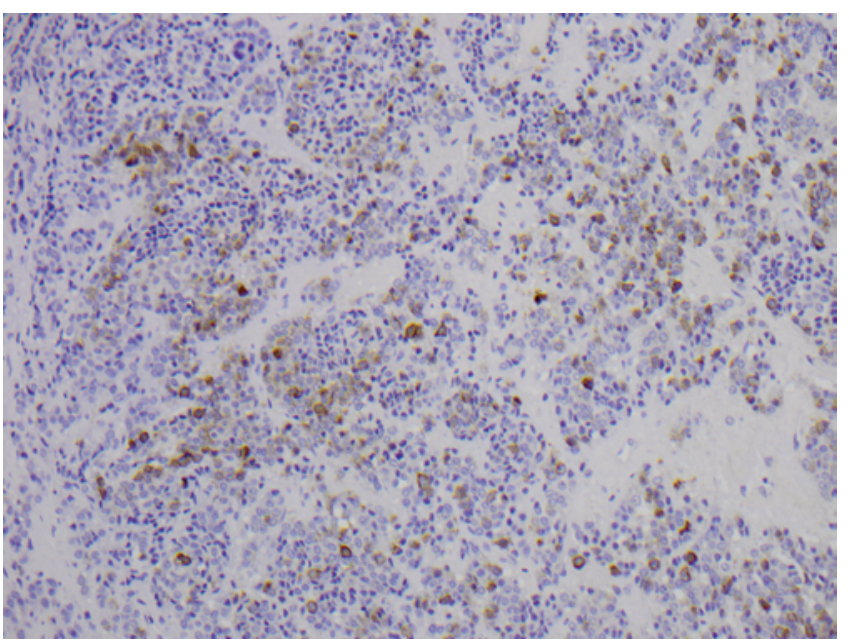

FIG. 5. The sphenoid sinus tumor tested positive for ACTH by immunohistochemistry (brown reaction product). Original magnification $\times 200$. 
TABLE 1. Immediate and delayed postoperative laboratory results

\begin{tabular}{cccc}
\hline $\begin{array}{c}\text { Postop } \\
\text { Day }\end{array}$ & Cortisol $(\mu \mathrm{g} / \mathrm{dl})^{*}$ & Sodium $(\mathrm{mmol} / \mathrm{L}) \dagger$ & Potassium $(\mathrm{mmol} / \mathrm{L}) \ddagger$ \\
\hline 0 & $28(9: 00 \mathrm{PM})$ & 139 & 3.1 \\
\hline 1 & $13.2(5: 00 \mathrm{Am})$ & 143 & 3.4 \\
\hline \multicolumn{5}{c}{$8.2(11: 00 \mathrm{Am})$} \\
\hline 2 & $5.6(1: 36 \mathrm{PM})$ & \\
\hline & $9.5(11: 35 \mathrm{AM})$ & 142 & 3.2 \\
\hline 3 & $12.7(5: 33 \mathrm{PM})$ & & 3.5 \\
\hline 4 & $10.5(3: 10 \mathrm{AM})$ & 141 & 4.2 \\
\hline 9 & $32.7(6: 06 \mathrm{AM}) \S$ & 141 & 4.8 \\
\hline 22 & $20.7(\mathrm{AM})$ & 142 & 4.6 \\
\hline
\end{tabular}

* Morning reference range 4.6-20.6 $\mu \mathrm{g} / \mathrm{dl}$; evening reference range 1.8-13.6 $\mu \mathrm{g} / \mathrm{dl}$.

$\dagger$ Reference range $136-145 \mathrm{mmol} / \mathrm{L}$.

$\ddagger$ Reference range $13.4-4.8 \mathrm{mmol} / \mathrm{L}$

$\S$ Twenty-five milligrams of oral hydrocortisone twice per day for suspected secondary adrenal insufficiency was started subsequent to this test.

erence range 4.6-20.6 $\mu \mathrm{g} / \mathrm{dl}$ ) (Table 1). Despite elevated postoperative cortisol levels, the patient was believed, on the basis of clinical symptoms of headache, nausea, vomiting, and fatigue, to have secondary adrenal insufficiency. He was started on 25-mg twice-daily oral hydrocortisone replacement therapy. No evidence of diabetes insipidus was found. The patient was discharged 5 days after the operation.

The patient improved over the next several weeks, with rapid regression of his symptoms and signs of Cushing syndrome. His blood pressure and diabetes medications were discontinued within 1 month of surgery, and hydrocortisone replacement was discontinued 3 months after the operation. Roughly 1 month after surgery, the patient developed new-onset sinus tachycardia that was controlled with medication. He developed sinusitis requiring antibiotics and evaluation by an otolaryngologist 3 months after surgery. Follow-up MRI 8 weeks after surgery revealed gross-total resection, and the patient was cleared to return to work at that time. At the 6-month endocrinology follow-up, clinical remission of his symptoms was noted. Laboratory testing revealed a urinary free cortisol level of $14 \mu \mathrm{g} /$ day (reference range 11-84 $\mu \mathrm{g} /$ day). At the 10 -month neurosurgical follow-up, on the basis of serum morning cortisol levels and no evidence of tumor recurrence on MRI (Fig. 6), the patient remained in hormonal remission. The most recent endocrinology follow-up, 11 months after the operation, confirmed clinical remission (resolution of the diabetes mellitus, joint pain, and muscle weakness and a urinary free cortisol level of $19 \mu \mathrm{g} / \mathrm{day}$ [reference range 11-84 $\mu \mathrm{g} /$ day]).

\section{Results}

\section{Literature Review}

Ectopic ACTH Adenomas Arising Within the Sphenoid Sinus

The search yielded 84 results, of which 47 were analyzed on the basis of relevancy. Fourteen cases were selected on the basis of the inclusion/exclusion criteria. Four additional cases, from Pluta et al., ${ }^{31}$ Morita et al., ${ }^{25}$ Srikantha et al., ${ }^{36}$ and Ritter et al., ${ }^{32}$ were found outside of the search; the Pluta et al. case was located within a mixed
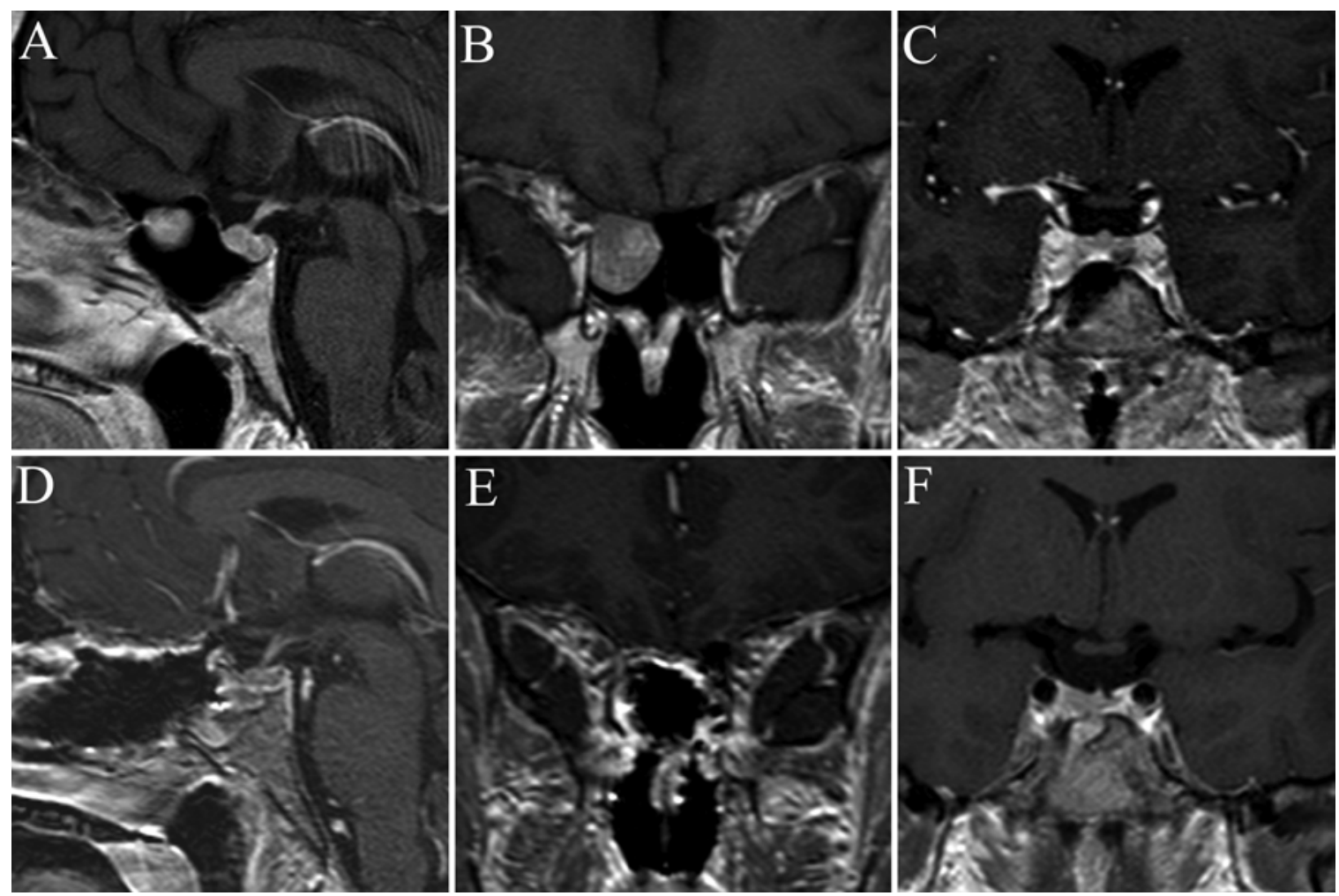

FIG. 6. Postoperative MR images (D-F) taken 3 months after surgery and preoperative MR images (A-C) for reference. 


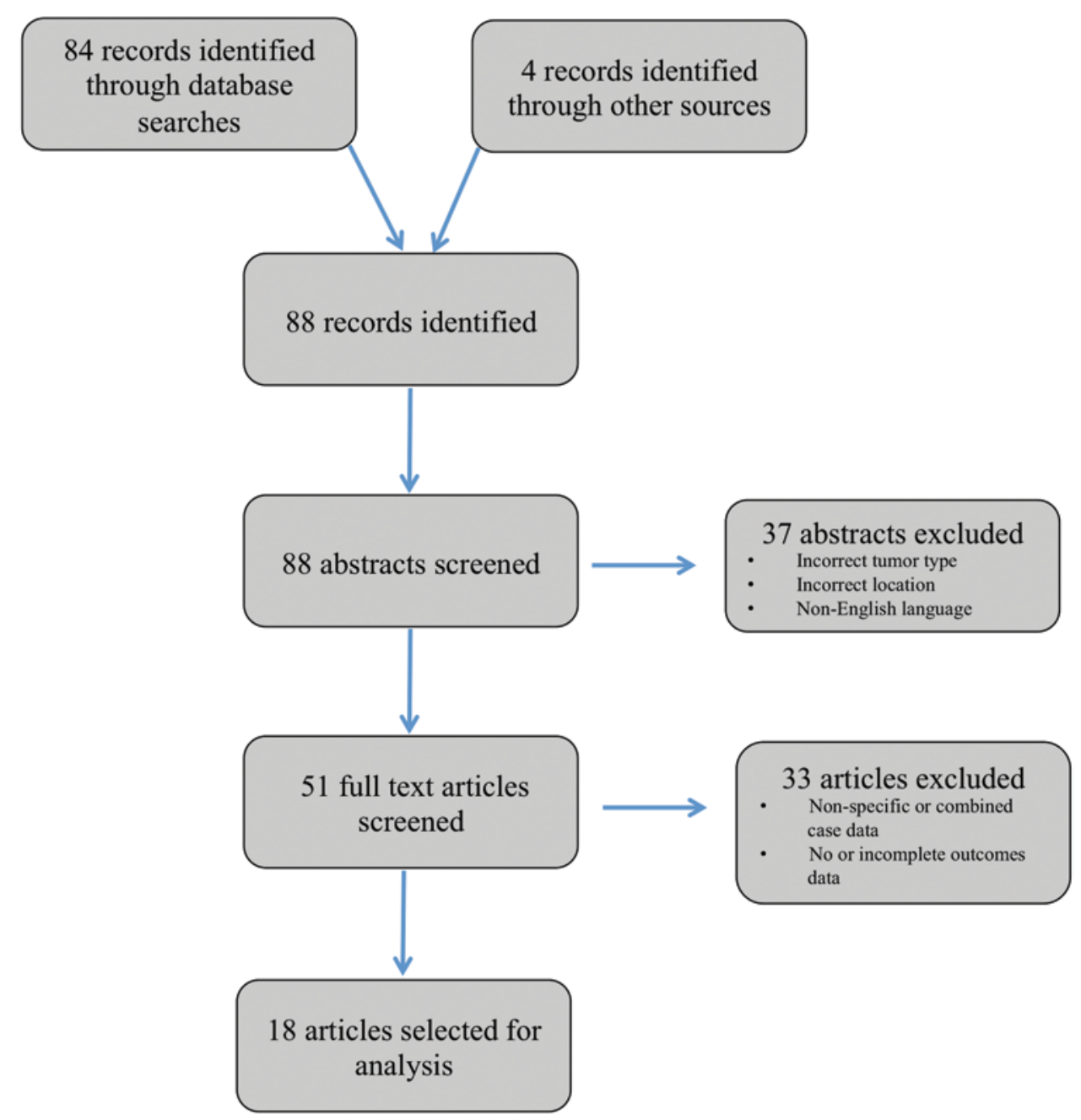

FIG. 7. PRISMA diagram for the literature search for ectopic pituitary adenomas of the sphenoid sinus.

case series found during the general ectopic literature review, whereas the Ritter et al., Morita et al., and Srikantha et al. reports were cited in another source. ${ }^{17}$ This information is summarized in Fig. 7. The Ritter et al., Morita et al., and Srikantha et al. articles were not indexed in PubMed. Nineteen cases, including our own, were included in the following focused review and analysis.

Patient ages ranged from 16 to 76 years, and there were 15 women and 4 men. For 13 of the 19 cases, the sizes of the resected masses were reported; the mean was $13.9 \mathrm{~mm}$ and the median was $8 \mathrm{~mm}$ (range 3-55 mm). Seven were microadenomas $(<1 \mathrm{~cm})$. The appearance on gross examination was consistently described as polypoid. Most were described as covered by sinus mucosa. No sellar or cavernous sinus invasion was noted, although Coire et al. ${ }^{8}$ described a thinning of the anterior sellar wall in 1 case. For the 15 cases that reported a serum ACTH level, the mean was $106.7 \mathrm{pg} / \mathrm{ml}$. The lowest preoperative ACTH level reported was used for this average when specific morning ACTH measurements were not noted. Four reports did not include serum ACTH measurements. For 10 cases serum morning cortisol levels were reported, the mean of which was $32.5 \mu \mathrm{g} / \mathrm{dl}$. Four cortisol measurements were excluded on the basis of inappropriate reporting or unknown timing, and 5 articles did not report serum cortisol levels.

Gross-total resection was achieved for all but 1 patient, and full and durable hormonal remission of Cushing syndrome was achieved for all of them. For the 13 for whom follow-up times were reported, the mean was 20 months. No significant complications were noted. Twelve patients required postoperative hydrocortisone supplementation. Two patients underwent bilateral adrenalectomy, which resulted in 1 case of Nelson syndrome. Two patients were treated with hemihypophysectomy. One had a total hypophysectomy, resulting in panhypopituitarism that was treated with hormone replacement. One patient had a partial resection that resulted in persistently elevated ACTH and serum cortisol levels, but these levels were found to be responsive to dexamethasone suppression and no further treatment was noted. One patient had a recurrent adenoma and was treated successfully with external-beam radiation therapy.

\section{All Ectopic ACTH Adenomas}

The search yielded 233 results, of which 77 results were analyzed. After application of the inclusion/exclusion cri- 
TABLE 2. Literature review: ectopic pituitary adenomas within the sphenoid sinus

\begin{tabular}{|c|c|c|c|c|c|c|c|}
\hline Authors \& Year & $\begin{array}{l}\text { Age (yrs), } \\
\text { Sex }\end{array}$ & Location & Size & $\begin{array}{l}\text { Serum ACTH } \\
\quad(\mathrm{pg} / \mathrm{ml})\end{array}$ & $\begin{array}{l}\text { Morning } \\
\text { Cortisol }(\mu \mathrm{g} / \mathrm{dl})\end{array}$ & Treatment & Outcome \\
\hline Present case & $48, M$ & $\begin{array}{l}\text { Rt superior sphe- } \\
\text { noid sinus }\end{array}$ & $1.8 \mathrm{~cm}$ & 195.7 & 51 & $\begin{array}{l}\text { Endoscopic endonasal } \\
\text { transsphenoidal op }\end{array}$ & $\begin{array}{l}\text { Hypocortisolemia after op, required } \\
\text { HRT for } 3 \text { mos; full remission } \\
\text { after resection (11-mo FU) }\end{array}$ \\
\hline $\begin{array}{l}\text { Flitsch et al., } \\
2014\end{array}$ & $50, F$ & $\begin{array}{l}\text { Inferior sphenoid } \\
\text { sinus }\end{array}$ & $5 \mathrm{~mm}$ & NR & NR & $\begin{array}{l}\text { Microscopic endona- } \\
\text { sal transsphenoidal } \\
\text { op }\end{array}$ & $\begin{array}{l}\text { Hypocortisolemia after op, required } \\
\text { HRT for } 3 \text { mos; full remission } \\
\text { after resection (FU unknown) }\end{array}$ \\
\hline $\begin{array}{l}\text { Ritter et al., } \\
\quad 2012\end{array}$ & $50, F$ & $\begin{array}{l}\text { Inferior sphenoid } \\
\text { sinus }\end{array}$ & NR & NR & NR & Transsphenoidal op & $\begin{array}{l}\text { Hypocortisolemia after op, required } \\
\text { HRT for } 3 \text { mos; full remission } \\
\text { after resection (3-mo FU) }\end{array}$ \\
\hline $\begin{array}{l}\text { Trulea et al., } \\
2009\end{array}$ & $55, F$ & $\begin{array}{l}\text { Septal; rt sphe- } \\
\text { noid sinus }\end{array}$ & $6 \mathrm{~mm}$ & 30.5 & NR & $\begin{array}{l}\text { Transnasal, transsep- } \\
\text { tal op }\end{array}$ & $\begin{array}{l}\text { Full remission after resection (12- } \\
\text { mo FU) }\end{array}$ \\
\hline $\begin{array}{l}\text { Zerikly et al., } \\
2009\end{array}$ & $39, \mathrm{M}$ & $\begin{array}{l}\text { Septal; It sphe- } \\
\text { noid sinus }\end{array}$ & $5 \mathrm{~mm}$ & NR & 61 & $\begin{array}{l}\text { Endoscopic endonasal } \\
\text { transsphenoidal op }\end{array}$ & $\begin{array}{l}\text { Hypocortisolemia after op, required } \\
\text { HRT for } 3 \text { mos; full remission } \\
\text { after resection (18-mo FU) }\end{array}$ \\
\hline $\begin{array}{l}\text { Suzuki et al., } \\
2004\end{array}$ & $32, F$ & Sphenoid sinus & $3 \mathrm{~cm}$ & 196 & $\begin{array}{l}23 \text { (unknown } \\
\text { timing) }\end{array}$ & $\begin{array}{l}\text { Endoscopic endonasal } \\
\text { transsphenoidal op; } \\
\text { dexamethasone } \\
\text { after op }\end{array}$ & $\begin{array}{l}\text { Partial resection achieved; serum } \\
\text { ACTH \& cortisol remained high } \\
\text { after resection, but Cushing } \\
\text { syndrome did not develop before } \\
\text { or after op because of large } \\
\text { amounts of biologically less ac- } \\
\text { tive, HMW ACTH (FU unknown) }\end{array}$ \\
\hline $\begin{array}{l}\text { Bethge et al., } \\
1999\end{array}$ & $32, \mathrm{M}$ & Lt sphenoid sinus & $1 \mathrm{~cm}$ & 80 & 38.2 & $\begin{array}{l}\text { Transnasal transsep- } \\
\text { tal op }\end{array}$ & $\begin{array}{l}\text { Full remission after resection (6-mo } \\
\text { FU) }\end{array}$ \\
\hline $\begin{array}{l}\text { Pluta et al., } \\
1999\end{array}$ & $27, \mathrm{M}$ & $\begin{array}{l}\text { Lt superior sphe- } \\
\text { noid sinus }\end{array}$ & NR & 119 & $\begin{array}{l}34 \text { (unknown } \\
\text { timing) }\end{array}$ & $\begin{array}{l}\text { Hemihypophysectomy; } \\
\text { transsphenoidal op }\end{array}$ & $\begin{array}{l}\text { Hemihypophysectomy failed to re- } \\
\text { solve symptoms; full remission } \\
\text { after resection (FU unknown) }\end{array}$ \\
\hline $\begin{array}{l}\text { Coire et al., } \\
\quad 1997\end{array}$ & $38, F$ & Lt sphenoid sinus & NR & 72.7 & 25.4 & $\begin{array}{l}\text { Transnasal sphe- } \\
\text { notomy }\end{array}$ & $\begin{array}{l}\text { Hypocortisolemia after op, required } \\
\text { temporary hydrocortisone re- } \\
\text { placement; full remission after } \\
\text { resection (12-mo FU) }\end{array}$ \\
\hline $\begin{array}{l}\text { Esteban et al., } \\
1997\end{array}$ & $38, F$ & Lt sphenoid sinus & NR & NR & NR & Open rhinoplasty & $\begin{array}{l}\text { Nelson syndrome developed after } \\
\text { adrenalectomy; full remission } \\
\text { after resection (36-mo FU) }\end{array}$ \\
\hline
\end{tabular}


TABLE 2. Literature review: ectopic pituitary adenomas within the sphenoid sinus (continued)

\begin{tabular}{|c|c|c|c|c|c|c|c|}
\hline Authors \& Year & $\begin{array}{l}\text { Age (yrs), } \\
\text { Sex }\end{array}$ & Location & Size & $\begin{array}{l}\text { Serum ACTH } \\
(\mathrm{pg} / \mathrm{ml})\end{array}$ & $\begin{array}{c}\text { Morning } \\
\text { Cortisol }(\mu \mathrm{g} / \mathrm{dl})\end{array}$ & Treatment & Outcome \\
\hline $\begin{array}{l}\text { Morita et al., } \\
1994\end{array}$ & $60, F$ & Sphenoid sinus & $5.5 \mathrm{~cm}$ & 74.5 & 22.5 & $\begin{array}{l}\text { Endonasal transsphe- } \\
\text { noidal op; hypophy- } \\
\text { sectomy }\end{array}$ & $\begin{array}{l}\text { Required } 4 \text { ops to resect tumor } \\
\text { fully; reserpine \& dexametha- } \\
\text { sone used after 3rd op; hypophy- } \\
\text { sectomy performed along w/ final } \\
\text { tumor resection; full remission af- } \\
\text { ter resection w/ panhypopituita- } \\
\text { rism requiring hormone replace- } \\
\text { ment (FU unknown) }\end{array}$ \\
\hline $\begin{array}{l}\text { Slonim et al., } \\
1993\end{array}$ & $76, F$ & Sphenoid sinus & $2 \mathrm{~cm}$ & 256 & 21.3 (PM) & $\begin{array}{l}\text { Transnasal transseptal } \\
\text { op; external-beam } \\
\text { radiation }\end{array}$ & $\begin{array}{l}\text { Full remission after resection; el- } \\
\text { evation in serum cortisol \& ACTH } \\
\text { returned, radiation eliminated } \\
\text { residual tumor (FU unknown) }\end{array}$ \\
\hline $\begin{array}{l}\text { Schteingart et } \\
\text { al., } 1987\end{array}$ & $49, F$ & $\begin{array}{l}\text { Anterior sphenoid } \\
\text { sinus }\end{array}$ & $8 \mathrm{~mm}$ & 176 & 33 & $\begin{array}{l}\text { Bilat adrenalectomy; } \\
\text { unknown trans- } \\
\text { sphenoidal op }\end{array}$ & $\begin{array}{l}\text { Hypocortisolemia after op, required } \\
\text { HRT; full remission after resec- } \\
\text { tion (36-mo FU) }\end{array}$ \\
\hline $\begin{array}{l}\text { Burch et al., } \\
\quad 1985\end{array}$ & $43, F$ & $\begin{array}{l}\text { Superior sphe- } \\
\text { noid sinus }\end{array}$ & $1.0 \mathrm{~cm}$ & 40 & NR & $\begin{array}{l}\text { Unknown transsphe- } \\
\text { noidal op }\end{array}$ & $\begin{array}{l}\text { Hypocortisolemia after op, required } \\
\text { HRT; full remission after resec- } \\
\text { tion (FU unknown) }\end{array}$ \\
\hline $\begin{array}{l}\text { Kammer \& } \\
\text { George, } \\
1981\end{array}$ & $51, \mathrm{~F}$ & Sphenoid sinus & NR & 152 & 18.8 & $\begin{array}{l}\text { Bilat adrenalectomy; } \\
\text { unknown trans- } \\
\text { sphenoidal op }\end{array}$ & $\begin{array}{l}\text { Hypocortisolemia after op, required } \\
\text { HRT; full remission after resec- } \\
\text { tion (19-mo FU) }\end{array}$ \\
\hline
\end{tabular}

$\mathrm{FU}=$ follow-up; HMW = high-molecular-weight; HRT = hydrocortisone replacement therapy; NR = not reported.

teria, 38 cases of ectopic ACTH-producing pituitary adenomas were included in this review. Including the 3 cases found outside of the search (noted above) and our own case, a total of 42 cases are summarized in Tables 2 and 3.

\section{Discussion}

Most patients diagnosed with Cushing syndrome will subsequently be found to have Cushing disease, the result of a central ACTH-secreting pituitary adenoma. The remainder of the patients will have ACTH-dependent disease from an ectopic source or a non-ACTH-dependent subtype. True ectopic pituitary adenomas are rare clinical-pathological entities, and their development, behavior, and biochemical profile are still largely undetermined. For example, our patient presented with high-dose dexamethasone-suppression test results mostly consistent with an ectopic (i.e., nonpituitary) source. Given that the cause was a functional pituitary adenoma, this result appears to be inconsistent with the known feedback-inhibition pattern found in functional ACTH-secreting pituitary adenomas. Suzuki et al. ${ }^{37}$ performed a literature review and found a variable response to dexamethasone suppression in multiple other cases. It is likely that these tumors behave differently than central adenomas in terms of glucocorticoid suppression.

We report here the 19th known ACTH-producing ectopic pituitary adenoma arising purely in the sphenoid sinus. Although their exact origin is unknown, it is thought that ectopic pituitary adenomas arise from remnants of the Rathke pouch during its developmental course. Because of this common origin with normal pituitary tissue, adenomas that form from this ectopic tissue often retain the same general features and functional variability as normal pituitary adenomas. ${ }^{22}$ These tumors, therefore, can be found purely within the nasopharynx, sphenoid sinus, cavernous sinus, clivus, or suprasellar region. ${ }^{16,22}$ Suprasellar origins in the third ventricle, hypothalamus, and interpeduncular cistern without any sellar communication have been reported. It is not definitively known what factors influence their location or contribute to the formation of ectopic pituitary adenomas. ${ }^{3}$

Given the diversity of locations and adenoma sizes, otherwise standard stepwise investigations into the underlying cause of clinically diagnosed Cushing syndrome can be frustrated by an occult ectopic adenoma. Failure to locate an ectopic ACTH-secreting adenoma promptly can result in the use of permanently destructive or ablative procedures such as bilateral adrenalectomy and hypophysectomy. Bilateral adrenalectomy remains a viable treatment option for those with refractory Cushing syndrome despite the risk of it causing Nelson syndrome..$^{14,31}$ Given the high mortality rate for those with nonpituitary Cushing syndrome (44\% at 10 years, in stark contrast to just $3 \%$ with Cushing disease), ${ }^{30}$ the prompt identification and removal of a functioning ectopic pituitary adenoma is essential and can result in a rapid and durable remission. ${ }^{18,21}$

Given the severity of the disease, patients presenting with Cushing syndrome from an unknown source should always be evaluated for the possibility of an ectopic pituitary adenoma. These tumors are exceedingly rare; roughly 90 cases of all types of ectopic pituitary adenomas ${ }^{17}$ have been reported since Erdheim published the first case in $1909 .{ }^{10}$ Our literature review of all functional ACTH-secreting ectopic pituitary adenomas identified 34 published cases of functional ACTH-producing ectopic 
TABLE 3. Literature review: ectopic ACTH adenomas outside the sphenoid sinus

\begin{tabular}{|c|c|c|c|c|}
\hline Authors \& Year & $\begin{array}{l}\text { Age (yrs), } \\
\quad \text { Sex }\end{array}$ & Location & Treatment & Outcome \\
\hline $\begin{array}{l}\text { Koizumi et al., } \\
2011\end{array}$ & $40, \mathrm{~F}$ & Lt cavernous sinus & $\begin{array}{l}\text { Endoscopic endonasal trans- } \\
\text { sphenoidal op }\end{array}$ & Full remission after resection \\
\hline Wilson et al., 1995 & $50, F$ & Lt cavernous sinus & Unknown & Unknown \\
\hline $\begin{array}{l}\text { Hamon et al., } \\
2003\end{array}$ & $37, \mathrm{~F}$ & Rt cavernous sinus & Gamma Knife & Outcome NR \\
\hline Kim et al., 2003 & $61, \mathrm{~F}$ & Rt cavernous sinus & $\begin{array}{l}\text { Transnasal transsphenoidal op } \\
\text { \& hypophysectomy }\end{array}$ & $\begin{array}{l}\text { Hypophysectomy failed to resolve hypercortisolemia; pt died of } \\
\text { cardiac issues } 17 \text { days after op; adenoma found on autopsy }\end{array}$ \\
\hline \multirow[t]{4}{*}{ Pluta et al., 1999} & $36, \mathrm{~F}$ & Rt cavernous sinus & $\begin{array}{l}\text { Transsphenoidal hypophysec- } \\
\text { tomy; bilat adrenalectomy; } \\
\text { radiation }\end{array}$ & $\begin{array}{l}\text { Panhypopituitarism; Nelson syndrome developed after adre- } \\
\text { nalectomy; radiation successfully diminished tumor size \& } \\
\text { reduced symptoms }\end{array}$ \\
\hline & $20, F$ & $\begin{array}{l}\text { Medial dural wall of } \\
\text { rt cavernous si- } \\
\text { nus, clivus }\end{array}$ & $\begin{array}{l}\text { Ketoconazole; transsphenoidal } \\
\text { resection }\end{array}$ & Failed medical therapy; full remission after resection \\
\hline & $31, \mathrm{M}$ & $\begin{array}{l}\text { Medial dural wall } \\
\text { of rt cavernous } \\
\text { sinus }\end{array}$ & $\begin{array}{l}\text { Transsphenoidal hypophysec- } \\
\text { tomy; bilat adrenalectomy; } \\
\text { transsphenoidal op }\end{array}$ & $\begin{array}{l}\text { Panhypopituitarism; Nelson syndrome developed after adrenal- } \\
\text { ectomy; full remission \& vision restored after resection }\end{array}$ \\
\hline & $61, F$ & Parasellar dura & $\begin{array}{l}\text { Transsphenoidal hypophysec- } \\
\text { tomy }\end{array}$ & $\begin{array}{l}\text { Panhypopituitarism, CSF leak; symptoms did not resolve; pt } \\
\text { died } 2 \text { mos later of unrelated illness, ectopic adenoma found } \\
\text { at autopsy }\end{array}$ \\
\hline Sanno et al., 1999 & $62, \mathrm{~F}$ & Rt cavernous sinus & None & $\begin{array}{l}\text { Pt died suddenly of unrelated illness; ectopic adenoma found } \\
\text { at autopsy }\end{array}$ \\
\hline Hou et al., 2002 & $11, \mathrm{M}$ & Suprasellar region & $\begin{array}{l}\text { Transsphenoidal hypophysec- } \\
\text { tomy; pterional craniotomy }\end{array}$ & $\begin{array}{l}\text { Hypophysectomy failed, resulted in panhypopituitarism; full } \\
\text { remission after pterional craniotomy \& resection }\end{array}$ \\
\hline Jung et al., 2000 & $22, \mathrm{~F}$ & Suprasellar region & Subfrontal craniotomy & Full remission after resection \\
\hline $\begin{array}{l}\text { Murakami et al., } \\
1998\end{array}$ & $24, F$ & Suprasellar region & Transsphenoidal op & $\begin{array}{l}\text { Op performed twice (1st unsuccessful \& 2nd successful); CSF } \\
\text { leak occurred \& required repair; DI developed transiently; full } \\
\text { remission of symptoms }\end{array}$ \\
\hline \multirow[t]{3}{*}{ Dyer et al., 1994} & $13, M$ & Suprasellar region & Frontal craniotomy & $\begin{array}{l}\text { Full remission after resection; persistent mild panhypopituita- } \\
\text { rism as a result of stalk injury }\end{array}$ \\
\hline & $22, \mathrm{~F}$ & Suprasellar region & $\begin{array}{l}\text { Bilat adrenalectomy; unknown } \\
\text { medical management }\end{array}$ & $\begin{array}{l}\text { Nelson syndrome developed after adrenalectomy; pt refused } \\
\text { additional op; symptoms stable under medical management }\end{array}$ \\
\hline & $14, \mathrm{~F}$ & Suprasellar region & Gamma Knife & Remission of clinical syndrome \& reduction of adenoma size \\
\hline $\begin{array}{l}\text { Lindboe et al., } \\
1993\end{array}$ & $34, F$ & Suprasellar region & Unknown op & $\begin{array}{l}\text { Transient postop syndrome of inappropriate antidiuretic hor- } \\
\text { mone secretion; deep vein thrombosis; full remission after } \\
\text { resection }\end{array}$ \\
\hline Tal, 1993 & $32, F$ & Suprasellar region & Unknown craniotomy & $\begin{array}{l}\text { DI developed postop; reduced DM \& hypertension symptoms; } \\
\text { full remission after resection }\end{array}$ \\
\hline $\begin{array}{l}\text { Matsumura et al., } \\
1990\end{array}$ & $71, \mathrm{M}$ & Suprasellar region & Bifrontal craniotomy & $\begin{array}{l}\text { 3rd ventricular bleeding intraop; tumor left adherent to stalk; pt } \\
\text { died of unrelated illness during recovery }\end{array}$ \\
\hline Bonner et al., 1979 & $23, \mathrm{~F}$ & Parasellar region & $\begin{array}{l}\text { Unknown incomplete resec- } \\
\text { tion; bilat adrenalectomy }\end{array}$ & $\begin{array}{l}\text { Cushing syndrome developed after incomplete resection; Nel- } \\
\text { son syndrome developed after adrenalectomy; case was } \\
\text { unresolved as of publication }\end{array}$ \\
\hline $\begin{array}{l}\text { Takahata et al., } \\
1995\end{array}$ & $37, \mathrm{~F}$ & $\begin{array}{l}\text { Interpeduncular } \\
\text { cistern }\end{array}$ & Pterional craniotomy & Full remission after resection \\
\hline Veit et al., 2013 & $63, \mathrm{M}$ & $\begin{array}{l}\text { Lt nasal cavity, eth- } \\
\text { moid sinus, } \\
\text { maxillary sinus }\end{array}$ & Endoscopic transnasal op & Full remission after resection \\
\hline $\begin{array}{l}\text { Gurazada et al., } \\
2014\end{array}$ & $19, \mathrm{M}$ & $\begin{array}{l}\text { Posterior nasal } \\
\text { cavity }\end{array}$ & $\begin{array}{l}\text { Transsphenoidal op; bilat } \\
\text { adrenalectomy; endonasal } \\
\text { resection }\end{array}$ & $\begin{array}{l}\text { Transsphenoidal op removed a nonfunctioning mass, did not } \\
\text { resolve symptoms; Nelson syndrome developed after adre- } \\
\text { nalectomy; full remission after resection }\end{array}$ \\
\hline $\begin{array}{l}\text { Ortiz-Suarez \& } \\
\quad \text { Erickson, } 1975\end{array}$ & $15, F$ & $\begin{array}{l}\text { Superior orbital } \\
\text { fissure, clivus }\end{array}$ & $\begin{array}{l}\text { Rt transfrontal craniotomy; } \\
\text { postop radiation }\end{array}$ & Full remission after resection \& radiation \\
\hline
\end{tabular}

$\mathrm{DI}=$ diabetes insipidus; $\mathrm{DM}=$ diabetes mellitus; $\mathrm{pt}=$ patient. 
pituitary adenomas. This number, however, is in stark contrast to the thousands of $\mathrm{ACTH}$-producing sellar pituitary adenomas diagnosed annually, comprising $10 \%-15 \%$ of all treated pituitary adenomas. ${ }^{16}$

Because of the rarity of this condition, even experienced physicians may overlook the possibility of a functional ectopic pituitary adenoma as part of the differential diagnosis of Cushing syndrome. Similarly, an ectopic tumor location can lead to misdiagnosis. In our experience, ectopic tumors are most commonly mistaken for nasal or sinus polyps when found incidentally on a CT scan or noncontrast MRI. These misdiagnoses may result in delayed diagnosis and treatment, increased cost, and prolonged exposure to hypercortisolemia.

There are several limitations that may have constrained our review and report. On the basis of histopathology alone, it is impossible to be certain that the sphenoid sinus tumor arose from ectopic pituitary tissue. Although we believe, on the basis of clinical remission after resection and imaging/histopathological characteristics, that the sphenoid sinus tumor was in fact an ectopic pituitary adenoma, we cannot definitively prove this conclusion on the basis of the pathological analysis alone. Also, the current review was limited by the small number of patients included in the analysis and the susceptibility to publication bias. Nevertheless, ectopic ACTH adenomas are an important pathological entity of which neurosurgeons, endocrinologists, and other treating physicians should be mindful when evaluating patients with Cushing syndrome.

\section{Conclusions}

With this case report, we sought not only to provide the most up-to-date comprehensive literature review of cases of ectopic ACTH-producing adenomas as a cause of Cushing syndrome, but also to provide a reminder to consider this rare condition when evaluating any patient with Cushing syndrome. Exploration of any suspicious sinus masses as a source of ectopic ACTH secretion is especially important after a standard stepwise work-up for patients with hypercortisolemia because of the very real possibility of misdiagnosing a more benign growth. Finally, clinicians should continue to investigate and publish diverse cases of ectopic pituitary adenomas so that the behavior of these unusual tumors can be better understood.

\section{References}

1. Al-Gahtany M, Bilbao J, Kovacs K, Horvath E, Smyth HS: Juxtaposition of an ectopic corticotroph adenoma of the sphenoid sinus with orthotopic intrasellar corticotroph hyperplasia in a patient with Cushing disease. Case report. J Neurosurg 98:891-896, 2003

2. Aron DC, Findling JW, Tyrrell JB: Cushing's disease. Endocrinol Metab Clin North Am 16:705-730, 1987

3. Asa SL, Ezzat S: The pathogenesis of pituitary tumours. Nat Rev Cancer 2:836-849, 2002

4. Cushing H: The basophil adenomas of the pituitary body and their clinical manifestations (pituitary basophilism). Bull Johns Hopkins Hosp 50:137-196, 1932

5. Bethge H, Arlt W, Zimmermann U, Klingelhöffer G, Wittenberg G, Saeger W, et al: Cushing's syndrome due to an ectopic ACTH-secreting pituitary tumour mimicking occult paraneoplastic ectopic ACTH production. Clin Endocrinol (Oxf) 51:809-814, 1999
6. Bonner RA, Mukai K, Oppenheimer JH: Two unusual variants of Nelson's syndrome. J Clin Endocrinol Metab 49:23-29, 1979

7. Burch WM, Kramer RS, Kenan PD, Hammond CB: Cushing's disease caused by an ectopic pituitary adenoma within the sphenoid sinus. N Engl J Med 312:587-588, 1985

8. Coire CI, Horvath E, Kovacs K, Smyth HS, Ezzat S: Cushing's syndrome from an ectopic pituitary adenoma with peliosis: a histological, immunohistochemical, and ultrastructural study and review of the literature. Endocr Pathol 8:65-74, 1997

9. Dyer EH, Civit T, Abecassis JP, Derome PJ: Functioning ectopic supradiaphragmatic pituitary adenomas. Neurosurgery 34:529-532, 1994

10. Erdheim J: Über einen Hypophysen-Tumor von ungewöhnlichem. Sitz Beitr Path Anat 46:233-240, 1909

11. Esteban F, Ruiz-Avila I, Vilchez R, Gamero C, Gomez M, Mochon A: Ectopic pituitary adenoma in the sphenoid causing Nelson's syndrome. J Laryngol Otol 111:565-567, 1997

12. Flitsch J, Schmid SM, Bernreuther C, Winterberg B, Ritter MM, Lehnert H, et al: A pitfall in diagnosing Cushing's disease: ectopic ACTH-producing pituitary adenoma in the sphenoid sinus. Pituitary [epub ahead of print], 2014

13. Findling JW, Aron DC, Tyrrell JB, Shinsako JH, Fitzgerald PA, Norman D, et al: Selective venous sampling for ACTH in Cushing's syndrome: differentiation between Cushing disease and the ectopic ACTH syndrome. Ann Intern Med 94:647-652, 1981

14. Gurazada K, Ihuoma A, Galloway M, Dorward N, Wilhelm T, Khoo B, et al: Nasally located ectopic ACTH-secreting pituitary adenoma (EAPA) causing Nelson's syndrome: diagnostic challenges. Pituitary 17:423-429, 2014

15. Hamon M, Coffin C, Courthéoux P, Théron J, Reznik Y: Case report: Cushing disease caused by an ectopic intracavernous pituitary microadenoma: case report and review of the literature. J Comput Assist Tomogr 27:424-426, 2003

16. Hou L, Harshbarger T, Herrick MK, Tse V: Suprasellar adrenocorticotropic hormone-secreting ectopic pituitary adenoma: case report and literature review. Neurosurgery 50:618-625, 2002

17. Johnston PC, Kennedy L, Weil RJ, Hamrahian AH: Ectopic ACTH-secreting pituitary adenomas within the sphenoid sinus. Endocrine 47:717-724, 2014

18. Jung S, Kim JH, Kim TS, Lee MC, Seo JJ, Park JW, et al: Supradiaphragmatic ectopic adrenocorticotropic hormonesecreting adenoma. Pathol Int 50:901-904, 2000

19. Kammer H, George R: Cushing's disease in a patient with an ectopic pituitary adenoma. JAMA 246:2722-2724, 1981

20. Kim LJ, Klopfenstein JD, Cheng M, Nagul M, Coons S, Fredenberg $\mathrm{C}$, et al: Ectopic intracavernous sinus adrenocorticotropic hormone-secreting microadenoma: could this be a common cause of failed transsphenoidal surgery in Cushing disease? Case report. J Neurosurg 98:1312-1317, 2003

21. Koizumi M, Usui T, Yamada S, Fujisawa I, Tsuru T, Nanba $\mathrm{K}$, et al: Successful treatment of Cushing's disease caused by ectopic intracavernous microadenoma. Pituitary 14:295298,2011

22. Langford L, Batsakis JG: Pituitary gland involvement of the sinonasal tract. Ann Otol Rhinol Laryngol 104:167-169, 1995

23. Lindboe CF, Unsgård G, Myhr G, Scott H: ACTH and TSH producing ectopic suprasellar pituitary adenoma of the hypothalamic region: case report. Clin Neuropathol 12:138-141, 1993

24. Matsumura A, Meguro K, Doi M, Tsurushima H, Tomono Y: Suprasellar ectopic pituitary adenoma: case report and review of the literature. Neurosurgery 26:681-685, 1990

25. Morita H, Yasuda K, Nakashima K, Noritake N, Murayama M, Shimokawa K, et al: Cushing's syndrome caused by an 
ectopic pituitary adenoma of the sphenoid sinus: adrenal crisis after partial resections of the adenoma. Endocr Pathol 5:123-130, 1994

26. Murakami N, Furuto-Kato S, Fujisawa I, Ohyama K, Nakao $\mathrm{S}$, Kuwayama A, et al: Supra- and extrasellar pituitary microadenoma as a cause of Cushing's disease. Endocr J 45:631636,1998

27. Newell-Price J, Bertagna X, Grossman AB, Nieman LK: Cushing's syndrome. Lancet 367:1605-1617, 2006

28. Nieman LK, Biller BM, Findling JW, Newell-Price J, Savage MO, Stewart PM, et al: The diagnosis of Cushing's syndrome: an Endocrine Society Clinical Practice Guideline. J Clin Endocrinol Metab 93:1526-1540, 2008

29. Ortiz-Suarez H, Erickson DL: Pituitary adenomas of adolescents. J Neurosurg 43:437-439, 1975

30. Oßwald A, Plomer E, Dimopoulou C, Milian M, Blaser R, Ritzel K, et al: Favorable long-term outcomes of bilateral adrenalectomy in Cushing's disease. Eur J Endocrinol 171:209-215, 2014

31. Pluta RM, Nieman L, Doppman JL, Watson JC, Tresser N, Katz DA, et al: Extrapituitary parasellar microadenoma in Cushing's disease. J Clin Endocrinol Metab 84:2912-2923, 1999

32. Ritter M, Burkhardt T, Schmid S, Bernreuther C, Winterberg $\mathrm{B}$, Lehnert H, et al: Pitfalls in Cushing's disease: report of an ectopic ACTH-producing pituitary adenoma in the sphenoid sinus. Endocrine Abstracts 29:P1458, 2012 (Abstract)

33. Sanno N, Tahara S, Yoshida Y, Onose H, Wakabayashi I, Teramoto A: Ectopic corticotroph adenoma in the cavernous sinus: case report. Neurosurgery 45:914-918, 1999

34. Schteingart DE, Chandler WF, Lloyd RV, Ibarra-Perez G: Cushing's syndrome caused by an ectopic pituitary adenoma. Neurosurgery 21:223-227, 1987

35. Slonim SM, Haykal HA, Cushing GW, Freidberg SR, Lee AK: MRI appearances of an ectopic pituitary adenoma: case report and review of the literature. Neuroradiology 35:546548,1993

36. Srikantha U, Khanapure K, Mohan M, Varma RG: Sphenoidal ectopic ACTH-secreting pituitary adenoma. JPMS 2:59-63, 2012

37. Suzuki J, Otsuka F, Ogura T, Kishida M, Takeda M, Tamiya T, et al: An aberrant ACTH-producing ectopic pituitary adenoma in the sphenoid sinus. Endocr J 51:97-103, 2004

38. Takahata T, Katayama Y, Tsubokawa T, Oshima H, Yoshino A: Ectopic pituitary adenoma occurring in the interpeduncular cistern. Case report. J Neurosurg 83:1092-1094, 1995
39. Tal A: Cushing's disease caused by ectopic pituitary adenoma within the pituitary stalk. South Med J 86:249-250, 1993

40. Thompson LD, Seethala RR, Müller S: Ectopic sphenoid sinus pituitary adenoma (ESSPA) with normal anterior pituitary gland: a clinicopathologic and immunophenotypic study of 32 cases with a comprehensive review of the English literature. Head Neck Pathol 6:75-100, 2012

41. Trulea M, Patey M, Chaufour-Higel B, Bouquigny F, Longuebray A, Rousseaux P, et al: An unusual case of ectopic adrenocorticotropin secretion. J Clin Endocrinol Metab 94:384-385, 2009

42. Veit JA, Boehm B, Luster M, Scheuerle A, Rotter N, Rettinger G, et al: Detection of paranasal ectopic adrenocorticotropic hormone-secreting pituitary adenoma by Ga68-DOTANOC positron-emission tomography-computed tomography. Laryngoscope 123:1132-1135, 2013

43. Willhauck MJ, Pöpperl G, Rachinger W, Giese A, Auernhammer CJ, Spitzweg C: An unusual case of ectopic ACTH syndrome. Exp Clin Endocrinol Diabetes 120:6367,2012

44. Wilson CB, Mindermann T, Tyrrell JB: Extrasellar, intracavernous sinus adrenocorticotropin-releasing adenoma causing Cushing's disease. J Clin Endocrinol Metab 80:1774-1777, 1995

45. Zerikly RK, Eray E, Faiman C, Prayson R, Lorenz RR, Weil RJ, et al: Cyclic Cushing syndrome due to an ectopic pituitary adenoma. Nat Clin Pract Endocrinol Metab 5:174179,2009

\section{Author Contributions}

Conception and design: Seltzer, Lucas, Carmichael, Zada. Acquisition of data: Seltzer, Lucas, Commins, Zada. Analysis and interpretation of data: Seltzer, Lucas, Commins, A Lerner, Carmichael, Zada. Drafting the article: Seltzer. Critically revising the article: Seltzer, Commins, O Lerner, A Lerner, Carmichael, Zada. Reviewed submitted version of manuscript: all authors. Study supervision: Carmichael, Zada.

\section{Correspondence}

Justin Seltzer, Department of Neurosurgery, Keck School of Medicine of USC, 1200 N. State St., Ste. 3300, Los Angeles, CA 90033.email: jseltzer@usc.edu. 